УДК $811.161 .1+811.112 .2+7.02+316.344 .7$

Gertrud Pickhan

\title{
MEIN RUSSLAND. ANFÄNGE, THEMEN UND BILDER
}

\section{MY RUSSIA: THEMES AND IMAGES}

Professor Gertrud Pickhan, a historian from Berlin, speaks about how she first showed interest in Russia in her youth when she enrolled on a course of Russian in Dortmund. Besides getting acquainted with classical Russian literature, she also had cultural contacts, and trips to Russia, where she discovered Russian painters, especially Levitan and Repin that have been the driving force of her scholarly interest ever since. She has a wide range of research interests. Except for painting and the history of Pskov, she studies freethinking marginals and creative personalities in a totalitarian state.

Keywords: Russia; Germany; Eastern-European history; history of Russian culture; impressionism; realism in art; Berlin; Dortmund; Moscow; Pskov; visual history; Pax Mongolica; Levitan, Repin.

Schon lange ist es unter EthnologInnen üblich, selbstreflexiv die eigenen Prägungen und individuellen und sozialisationsbedingten Zugänge zum ausgewählten Forschungsfeld offen zu legen. In der Geschichtswissenschaft wird diese Praxis bislang kaum angewandt, obwohl gerade die Beschäftigung mit der Geschichte des östlichen Europa immer auch zahlreiche vorwissenschaftliche Implikationen hat. So ist die Vorstellung einer Rückständigkeit des Ostens im Vergleich zur Zivilisation und Demokratie westlicher Prägung nach wie vor weit verbreitet. Erst das Konzept der multiple modernities erlaubt es, die osteuropäische Geschichte nicht als negative Projektion westlicher Überlegenheitsgefühle zu sehen, was nicht heißt, die Verwerfungen und menschenverachtenden Praktiken, die der Geschichte Russlands immanent sind, auszublenden. Konzentriert man sich jedoch nur auf sie, entsteht ein Narrativ, das den Menschen und ihren historischen Lebenswelten nicht gerecht wird.

\section{Ausgangspunkt: Dortmund (1973-1974)}

Wodurch wird Forschungsinteresse geweckt? Diese Frage wird noch viel zu selten gestellt, obwohl sie nicht nur Einsichten in die individuellen Voraussetzungen liefert, sondern auch generationsspezifische Sichtweisen erhellen kann. Ein Blick zurück in die 1970er Jahre in einer Stadt im tiefen 
Westen der Bundesrepublik: Dortmund. Als Arbeiterstadt war Dortmund traditionell sozialdemokratisch geprägt und nahm daher die Impulse der „Neuen Ostpolitik“ unter Willy Brandt bereitwillig auf. Insbesondere die Rheinisch-Westfälische Auslandsgesellschaft (heute: Auslandsgesellschaft Nordrhein-Westfalen) legte ein großes Engagement und viel Kreativität an den Tag bei dem Versuch, den DortmunderInnen die Welt hinter dem Eisernen Vorhang näher zu bringen. Eine wichtige Voraussetzung für ein besseres Kennenlernen ist immer eine gemeinsame Sprache, und so organisierte die Auslandsgesellschaft fakultative Russisch-Kurse für Dortmunder GymnasiastInnen. Da ich mich für Sprachen interessierte und im Englischen und Französischen schon recht fit war, entschied ich mich, einen solchen Kurs $\mathrm{zu}$ besuchen. Meine Eltern, beide VolksschullehrerInnen und Angehörige der Kriegsgeneration (Jahrgang 1917 und 1922), hatten nichts dagegen, obwohl der Antikommunismus und Vorbehalte gegenüber dem „Ostblock“ in bürgerlichen Kreisen Westdeutschlands weit verbreitet waren. Sprachlich brachte mich der Russischkurs allerdings nicht viel weiter, da unser Lehrer ein tschechischer Emigrant war, der 1968 aus Prag geflohen war und daher keine große Motivation zeigte, uns die Schönheiten der russischen Sprache und Kultur zu offenbaren. Doch schmälerte dies nicht meine Begeisterung für die russische Literatur, insbesondere Anton Chekhov, die ich zumindest in deutscher Übersetzung lesen konnte.

Auch ließ sich die Dortmunder Auslandsgesellschaft noch viel mehr einfallen, um den DortmunderInnen ein facettenreiches Bild der Großmacht im Osten zu zeigen. 1957 hatte man damit begonnen, Auslandskulturtage mit Länderschwerpunkten zu organisieren. Den Anfang machte Schweden, das erste Land des „Ostblocks“ war 1971 die Volksrepublik Ungarn. 1973 war es dann so weit: „Die Sowjetunion. Auslandskulturtage der Stadt Dortmund 14-25 Mai 73“ (Il. 1). Zum Vokabellernen und Grammatikpauken kam nun das Beste, was die offizielle sowjetische Kultur der Brezhnev-Zeit zu bieten hatte. Das Programm der Veranstaltungen im Rahmen dieser Auslandskulturtage umfasst 37 Seiten und reicht vom Auftritt des BolschoiBallets im Dortmunder Stadttheater bis zu russischen Kochkursen im Hotel Römischer Kaiser. Zum festliche Auftakt, der in Verbindung mit der Eröffnung der Ausstellung „Der Weltraum für den Frieden” im Goldsaal der Dortmunder Westfalenhalle stattfand, erschienen neben dem Dortmunder Bürgermeister Günter Samtlebe und dem Ministerpräsidenten des Landes Nordrheinwestfalen (beide SPD) auch der Botschafter der UdSSR Valentin Falin, der bereits vor seinem Antritt als Botschafter in Bonn 1971 in Moskau an der Ausarbeitung des Moskauer Vertrags zwischen der UdSSR und der Bundesrepublik Deutschland mitgewirkt hatte. Falin eroberte mit seinem Charme und seinem Humor, die ihn ganz anders wirken ließen als die Vertreter der Sowjetmacht, die man aus dem Fernsehen kannte, die Herzen der DortmunderInnen, unvergesslich ist ein sprachlicher Lapsus, mit dem sich Falin zum „Herrenschirm“ statt zum „Schirmherrn“ erklärte.

Gleich am ersten Abend der Auslandskulturtage erlebte ich eine Vorstellung, die für mich der absolute Höhepunkt war: Maja Plisetskajas Ballett 
„Anna Karenina“ im Großen Haus der Städtischen Bühnen Dortmund. Ich war hingerissen und zutiefst beglückt. Das war große Kunst auf der Höhe der Zeit und dennoch in der Tradition der russischen Kultur, die ich aus Tolstojs Romanen und Chekhovs Erzählungen kannte. Die Begeisterungsfähigkeit eines Teenagers trug gewiss zu dem tiefen Eindruck bei, den diese Vorstellung bei mir hinterließ. Ganz anders reagierten freilich die Studienrätinnen meines als eher konservativ eingeschätzten Dortmunder Gymnasiums. Die harmlose Vorstellung des Staatlichen Puppentheaters Moskau unter der Leitung von Sergej Obraztsov in der Aula des Gymnasiums diente aus ihrer Sicht ausschließlich der kommunistischen Unterwanderung der Dortmunder Kinder und Jugendlichen. Ähnlich ablehnend verhielten sich unsere Lehrerinnen auch 1974, als wir Schülerinnen Prag als Ziel der großen Klassenreise in der Unterprima auswählten. Als Grund für die Ablehnung wurde angeführt, dass in Prag hinter jeder Ecke „ein schöner Mann aus Moskau“ lauere, der nur auf Dortmunder Gymnasiastinnen wartete und bei uns Teenagern bis zum Abitur ein geflügeltes Wort blieb. Gemeinsam mit meiner Mutter machte ich dann im Herbst 1974 eine Busreise nach Prag, wo die Nachwehen von 1968 immer noch zu spüren waren.

Ich erinnere nicht mehr genau, welche Veranstaltungen noch von mir besucht wurden. Das Angebot war groß und bunt. So enthielt das Programm unter anderem einen Vortrag der sowjetischen Kulturministerin Ekaterina Furceva (im Programm: „des sowjetischen Kulturministers“!) über die „Entwicklung der Kultur in der UdSSR und die kulturellen Auslandsbeziehungen mit der Bundesrepublik Deutschland“, Aufführungen des Staatlichen Russischen Gesangs- und Tanzensemble Pjatnickij, Kranzniederlegungen der sowjetischen Delegation an den Gedenkstätten für die Opfer des Zweiten Weltkriegs in Dortmund, Vorträge zur russischen und sowjetischen Literatur und zur Erwachsenenbildung in der UdSSR, Kunstturnen sowjetischer Spitzensportler, unter ihnen Olga Korbut, und verschiedene Begegnungen sowjetischer und Dortmunder BürgerInnen. Krönender Abschluss war ein Ball der Nationen in der Dortmunder Wetsfalenhalle, bei dem neben dem WDR-Tanzorchester auch das Staatliche Tanzorchester der SSR Armenien spielte - der Westdeutsche Rundfunk übertrug die Veranstaltung live im Radio.

Woran ich mich jedoch erinnere, ist, dass die Auslandskulturtage Sowjetunion in Dortmund auf großes Interesse stießen, selbst bei meinem Vater, der als junger Soldat am Russlandfeldzug der Deutschen Wehrmacht teilgenommen hatte. Über seine Erfahrungen sprach er nur höchst selten, manchmal tauchte der „Russki“ in seiner Sprache auf. Trotz aller Verdrängungsmechanismen erwähnte er mitunter, in russischer Kriegsgefangenschaft besser behandelt worden $\mathrm{zu}$ sein als in britischer. Heute bedauere ich zutiefst, dass ich meinen Vater, der 1995 verstarb, nicht nach seinen Erlebnissen im Krieg gefragt habe. Dass sie ihn in seiner Psyche tief beschädigt hatten, konnte ich nur ahnen. Ich las in jener Zeit jedoch mit großer Aufmerksamkeit die zutiefst menschlichen und berührenden Erzählungen Heinrich Bölls (wie mein Vater 1917 geboren), 
in denen dieser seine Kriegserlebnisse literarisch verarbeitete. Dass Böll in Russland gelesen und verehrt wurde, war mir bewusst und verstärkte noch mein Interesse an seinen Werken. Das Interview, das Klaus Bednarz 1979 mit Heinrich Böll und Lev Kopelev in Moskau führte und das unter dem Titel „Es gibt keinen Hass mehr..." im deutschen Fernsehen gezeigt wurde, gehört für mich bis heute zu den Sternstunden des Fernsehen.

In den Osterferien 1974 reiste ich dann in ganz anderer Absicht als mein Vater oder Heinrich Böll als Soldaten zusammen mit einer Gruppe Jugendlicher aus dem Russischkurs nach Moskau und Leningrad. Finanziert wurde diese Reise ebenfalls von der Rheinisch-Westfälischen Auslandsgesellschaft. Es war die erste große Reise, die ich ohne meine Eltern unternahm (die Zeiten ändern sich). Es müssen 8-10 Tage gewesen sein, in denen wir vom Büro für internationalen Jugendtourismus "Sputnik“ betreut wurden. „Sputnik“ hatte in Moskau und Leningrad auch Begegnungen mit russischen Jugendgruppen organisiert, die jedoch aufgrund der fehlenden Sprachkenntnisse kaum Gespräche ermöglichten. Das touristische Programm war beeindruckend - es hatte nach meiner Erinnerung zuvor auch ein Vorbereitungsprogramm in Dortmund gegeben. An nachhaltigsten erinnere ich jedoch eine frühabendliche Fahrt mit dem Bus über einen der großen Moskauer Prospekte. Etwas ermüdet von den Besichtigungen fiel mein Blick plötzlich auf die vielen erleuchteten Fenster hinter den grauen Mietshausfassaden, und auf einmal verspürte ich eine große Sehnsucht danach zu erfahren, was die Menschen hinter den Fassaden bewegt, was sie in ihren Wohnungen tun, welche Freunden und Sorgen sie haben. Und vielleicht - es mag sentimental klingen - war es dieser Moment der wichtigste Auslöser dafür, dass ich mich ein Jahr später entschied, ein Studium der Slawistik und der Osteuropäischen Geschichte aufzunehmen. Der Wunsch, hinter die Fassaden zu blicken und den Menschen wirklich zu begegnen erfüllte sich 1985, als ich als DFG-Stipendiatin im Rahmen meines Dissertationsvorhabens zur mittelalterlichen Stadtrepublik Pskov eine halbes Jahr in Moskau lebte und arbeitete [Pickhan, 1992]. Es war der Beginn der Perestrojka-Zeit, doch das ist schon ein anderes Kapitel.

Festzuhalten ist: Ich verdanke mein Interesse für Russland, seine Geschichte und Kultur Willy Brandt, der Neuen Ostpolitik und der Rheinisch-Westfälischen Auslandsgesellschaft in Dortmund. Auch einige andere OsteuropaexpertInnen, so z.B. mein Kollege Klaus Segbers, Professor für Politikwissenschaft am Osteuropainstitut der Freien Universität (Jg. 1954), erhielten die ersten Impulse für ihr Russland-Interesse in Dortmund. Hier tut sich aus meiner Sicht ein interessantes Forschungsfeld auf, das nach milieu- und generationsspezifischen Ursachen für die Beschäftigung mit Osteuropa fragt. Wohl kaum mehr beantworten lässt sich die Frage, die mir in den Sinn kommt, wenn ich die alten Fotos von 1974 anschaue (Il. 2). Westdeutsche Jugendliche mit Schlaghosen, die sich recht selbstbewusst und lässig auf Moskauer Straßen der Kamera präsentieren - wie haben wir wohl auf Moskauerinnen und Moskauer gewirkt? 
Es gibt jedoch noch etwas anderes, das mich aus der Gegenwart in das Moskau des Jahres 1974 zurückführt. Damals sah ich zum ersten Mal bei dem obligatorischen Besuch in der Tret'jakov-Galerie die Gemälde Isaak Levitans, die für mich seither zu einem wichtigem Bezugspunkt und seit einiger Zeit auch zu einem Forschungsgegenstand geworden sind. Jedes Mal, wenn ich mich in der russischen Metropole aufhalte, zieht es mich in einem einer Wallfahrt gleichenden Gang in den Saal mit den Werken Isaak Levitans. Wahrnehmung und Wirkung dieser Kunstprodukte des späten 19. Jahrhunderts erzeugen bei jedem Museumsbesuch dieselbe Erfahrung: Während außerhalb des Museums das Leben einer Millionenstadt pulsiert, das durch Hektik, Lärm und vorwärts drängende Menschenmassen im unterirdischen Metro-System gekennzeichnet ist, verdichtet sich oft nach mehrstündigen kontemplativen Betrachtungen der Landschaftsbilder Levitans mein „in Russland Sein“, und ich erlebe eine Visualisierung der Essenz meines Russland-Bildes. Ich begebe mich auf eine Zeitreise und in die Gegenwelt des Bildprogramms eines Malers und versuche die Rückkehr in die andere, oft brutale Wirklichkeit des MetropolenAlltags so lange wie möglich hinauszögern. Diese vorwissenschaftliche, subjektive Wahrnehmung ist jedoch keinesfalls nur meine individuelle Empfindung; sie ist wie jede Kunstrezeption kulturell kodiert. Eine ganz ähnliche Sinngebung erfolgte z.B. 2007 bei einer großen Ausstellung mit Gemälden aus der Tretj'akov-Galerie, die in der Kunsthalle Bonn gezeigt wurden. Auch hier fehlte Levitan nicht. Wie bereits der Titel der Bonner Ausstellung „Russlands Seele“ suggeriert, versprachen die Kuratoren ihren deutschen Besuchern „einen tiefen Einblick in Russlands Seele“. Dieses plakative Leitmotiv kann von postmodernen Kunstexperten als ironische Brechung eines gängigen Stereotyps verstanden werden. Im Katalog wurde die sinnstiftende Aufladung der Bilder als Ausdruck einer russischen Seele jedoch nicht in Frage gestellt.

\section{Visual History oder „Geschichte zerfällt in Bilder, nicht in Geschichten“ (W. Benjamin)}

2007 wurde ich eingeladen, mich mit einem Vortrag an einer Ringvorlesung zu beteiligen, die neue Perspektiven in den jüdischen Studien präsentieren sollte. Die osteuropäisch-jüdische Geschichte gehört zu meinen wichtigsten Arbeitsschwerpunkten, seit ich mich in meiner Habilitationsschrift der Geschichte des Allgemeinen Jüdischen Arbeiterbunds „Bund“ in Polen 1918-1939 gewidmet habe [Pickhan, 2001]. Auch dieses Forschungsinteresse geht zurück auf die 1970er Jahre und den Kniefall Willy Brandts vor dem Mahnmal des Warschauer Ghettos 1970, der zweifellos für mich zu den prägendsten politischen Ereignissen gehörte und mein Interesse für die von den Nazis grausam zerstörten osteuropäisch-jüdischen Lebenswelten weckte. Es begleitet mich nun schon seit über 40 Jahren. 
Als ich 2007 über ein Thema für die Potsdamer Ringvorlesung nachdachte, fiel mir Isaak Levitan ein. Inspiriert durch ein Buch meines israelischen Kollegen Ezra Mendelsohn über den polnisch-jüdischen Maler Maurycy Gottlieb, „Painting a people“ [Mendelsohn], begann ich mich nun auch wissenschaftlich mit Isaak Levitan zu beschäftigen. Ein erstes Ergebnis war die Veröffentlichung meines Vortrags, in dem ich drei jüdische Maler - Isaak Levitan, Maurycy Gottlieb und Max Liebermann - in vergleichender Perspektive in ihren unterschiedlichen historischen Kontexten - Russländisches Reich, Galizien, Preußen/Deutschland - untersuchte [Pickhan, 2008, S. 247-264]. In einem nächsten Schritt untersuchte dann ich die Rezeption eines einzigen Gemäldes Levitans, „Über der ewigen Ruhe" von seiner Entstehungszeit bis in die späte Sowjetzeit [Pickhan, 2011; Il. 3]. 2012 erschien ein Aufsatz, in welchem ich die Nachrufe untersuchte, die nach Levitans Tod im Sommer 1900 in der russischen Presse und Publizistik erschienen [Pickhan, 2012, S. 591-616].

Erst kürzlich vollendete ich einen weiteren Beitrag, der Levitans zeitgenössische Rezeption im deutschsprachigen Raum, insbesondere durch Rainer Maria Rilke, in den Blick nimmt und im kommenden Jahr in einem Sammelband $\mathrm{zu}$ den russisch-deutschen Kulturbeziehungen erscheinen soll. Es sind dies alles Vorstudien für ein Buch, in dem es nicht um Leben und Werk Levitans, sondern um seine Rezeption durch Zeitgenossen und Nachwelt gehen soll. Insbesondere interessiert mich die Frage, für wen, wann und warum Levitans jüdische Herkunft von Bedeutung war - oder nicht.

Ezra Mendelsohn und Isaak Levitan lenkten mein Forschungsinteresse auf die Visual History. Als ich 2007 wieder einmal in Moskau war und meinen rituellen Gang durch die Tret'jakovka machte, kam mir zum ersten Mal bei der Betrachtung der Gemälde des 19. Jahrhunderts der Gedanke, dass sich in ihnen alle großen Themen dieser Zeit widerspiegeln und man die Geschichte des 19. Jahrhunderts auch mit ihren Bildern als Quellen erzählen kann. Diese Erkenntnis setzte ich dann um in einer Vorlesung über die russische Geschichte des 19. Jahrhunderts im Spiegel der Malerei, die mir und den Studierenden viel Freude bereitete. Diese Vorlesung ist auch Grundlage für ein weiteres Buch, das ich plane. Auch dazu entstand bereits eine Vorstudie, in der ich den berühmten „Aufstand der Vierzehn“ und die Revolte St. Petersburger Kunststudenten gegen die Universitätsobrigkeit untersuchte [Pickhan, 2011, S. 171-184].

\section{Grundmuster meiner Forschungen}

Wenn ich nach Generallinien in meinen bisherigen Forschungen zur osteuropäischen Geschichte suche, so lassen sie sich unter drei Gesichtspunkten zusammenfassen. Zum einen geht es immer wieder um E man zipations- und Selbstermächtigungsprozesse. Das beginnt in meiner Dissertation mit der selbstverwalteten Pskover Stadtrepublik [Pickhan, 
1992], die wie Novgorod als Gegenmodell zum Moskauer Zentralismus gelten kann, und führte mich dann in meiner Habilitationsschrift zum Jüdischen Arbeiterbund in Polen, der den Angehörigen einer ethnisch und sozial ausgegrenzten Minderheit neues Selbstbewusstsein gab und ein frühes Konzept des modernen Multikulturalismus entwarf. Emanzipationsgeschichten sind auch der „Aufstand der Vierzehn“, der zum einem Nucleus für das spätere Erfolgsmodell der Peredvizhniki wurde, und die Geschichte des Jazz hinter dem Eisernen Vorhang, wo sich vornehmlich junge Menschen von den vorgegebenen Kulturformen abwandten und ihre eigene, ganz andere Musik machten. Letzteres war Gegenstand eines von mir geleiteten und von der VW-Stiftung geförderten Forschungsprojekts ${ }^{1}$. Gleichzeitig entstand auch in Zusammenarbeit mit dem Musikjournalisten Maximilian Preisler eine Biographie des Jazzmusiker Eddie Rosner, der seine Laufbahn im Berlin der späten 1920er Jahre begann, während des Krieges dann in der Sowjetunion zu einem Superstar aufstieg, selbst im Gulag noch Jazz machte und am Ende seines Lebens verarmt in seiner Geburtsstadt Berlin verstarb [Pickhan, Preisler].

Pskov, Jazz und Juden - dabei geht es um ein weiteres Grundthema: Außenseiter und „beautiful loosers“, die für mich viel interessanter sind als die großen Sieger und Helden der Geschichte. Die selbstverwaltete Stadtrepublik Pskov wurde schließlich vom Moskauer Großfürsten in sein zentralistisch regiertes Reich integriert, der „Bund“als Massenbewegung ging im Holocaust unter. Der Jazz war auch im „Ostblock“ nie wirklich „mainstream“, und dennoch nahmen seine Anhänger auch Repressionen in Kauf, um sich die schwarze Musik Amerikas anzueignen. Die osteuropäisch-jüdischen MigrantInnen im Berlin der Weimarer Zeit, denen ein weiteres größeres Forschungsprojekt gewidmet war, blieben ebenfalls diskriminiert und aus der Mehrheitsgesellschaft ausgegrenzt und bildeten dennoch einen facettenreichen und höchst kreativen Mikrokosmos ${ }^{2}$. Ihm entstammte auch Eddie Rosner, der so für mich zu einer Klammer zwischen beiden Projekten - über den Jazz und die osteuropäisch-jüdischen MigrantInnen in Berlin - wurde.

Und schließlich ist es für mich auch zu einem Grundanliegen geworden, das Rückständigkeitsparadigma in der russischen bzw. osteuropäischen Geschichte zu hinterfragen. Diesebeginntbereits im Mittelalter: Noch immer wird das „Tatarenjoch“ häufig als Grund für eine postulierte Rückständigkeit Russlands angesehen, die sich demnach bis in die Gegenwart fortsetzte. Jedoch scheinen neuere Forschungen plausibler, nach denen die mittelalterlich Rus' nach 1240 keinesfalls isoliert und auf sich selbst bzw. den asiatischen Despotismus zurückgeworfen war. Vielmehr war sie eingebunden in gewinnbringende „Pax Mongolica“ und ein großräumiges Handels- und Kommunikationsnetz [Pickhan, 2009, S. 113-137]. Damit ist bereits dem vielfach angenommenen Ursprung einer russischen Rückständigkeit im Mittelalter der Boden entzogen. Und blickt man ins 19. Jahrhundert, genauer in das Jahr 1863, so wird deutlich, dass

\footnotetext{
1 URL: http://www.oei.fu-berlin.de/projekte/jazz/index.html

2 URL: http://www.oei.fu-berlin.de/projekte/charlottengrad-scheunenviertel/index.html
} 
die 14 St. Petersburger Kunststudenten mit ihrem Bruch mit der Akademie einen Schritt vollzogen, den Künstler in Deutschland und Österreich mit den Sezessionsbewegungen der 1890er Jahre erst 30 Jahre später vollzogen.

\section{„Let us learn about the Russia...that gave rise to this painting“}

Auch der wohl berühmteste russische Maler des 19. Jahrhunderts Ilja Repin erhielt seine wichtigsten Prägungen im Umfeld der rebellischen jungen Künstler, mit einem der Vierzehn, Ivan Kramskoj, war Repin eng befreundet. „Auf der Suche nach Russland“ - so lautete der Titel einer Repin-Ausstellung, die 2003 in der Berliner Nationalgalerie zu sehen war. Mit der „Kreuzprozession im Gouvernement Kursk“, die bei der 11. Wanderausstellung $1883 \mathrm{zu}$ sehen war, gelang Repin ein ebenso monumentales wie differenziertes Kaleidoskop der russischen Gesellschaft seiner Zeit. Bis heute zieht dieses Gemälde nicht nur die vielen Besucher und Besucherinnen der Tret'jakov-Galerie in seinen Bann, sondern vermag auch einen amerikanischen Kunsthistoriker und Experten für die französische Malerei des 19. Jahrhunderts im fernen Texas zu begeistern. $\mathrm{Zu}$ Recht plädiert Richard R. Bretell dafür, die Werke der Wanderer zunächst einmal als Kunst und erst in einem zweiten Schritt als russisch anzusehen. Er weist darauf hin, dass die russischen Maler sowohl durch ihre Einbindung in einen nationalen Kontext wie auch durch ihre antiautoritäre Haltung Teil einer gesamteuropäischen Avantgarde-Bewegung waren:

„Realism, for the Russians, was part of a general European movement rather than an isolated response to Russian social and aesthetic conditions... Unlike the Impressionists and the various groups in France, they were well organized, made money, and succeeded in their aims of promoting Russian art throughout the country" [Bretell, p. 53].

Die Bewegung, die 1863 mit dem "Aufstand der Vierzehn" ihren Anfang nahm, macht somit deutlich, dass Russland kulturell und intellektuell keineswegs rückständig, sondern auf der Höhe der Zeit war. Dass die Maler in ihren Bildern das russische Leben gleichermaßen priesen und kritisierten, wie Bretell pointiert formuliert, vermittelt wohl kein Gemälde so anschaulich wie Repins Kreuzprozession. In der sich vorwärts bewegenden Masse sehen wir eine Gruppe traditionell gekleideter Bauern, einfache Frauen mit Kopftuch, Schulkinder mit ihrem streng und unfreundlich blickenden Lehrer, einen wohlgenährten Geistlichen mit einem vermutlich durch Alkoholkonsum geröteten Gesicht, eine matronenhafte Gutsbesitzerin, die die Ikone trägt, Uniformierte, die in die Menge prügeln. Die einzig beseelte Gestalt ist ein behinderter, schlecht gekleideter Junge. Mit Ausnahme der beiden ärmlich aussehenden, verängstigten Pilgerinnen hinter ihm scheint er der einzige zu sein, für den die religiösen Dimensionen dieses Ereignisses bedeutungsvoll sind, und es ist offensichtlich, dass diesem diskriminierten Außenseiter die ganze Sympathie des Malers gilt. Meisterlich versteht es Repin, den Betrachten- 
den gleichsam eine teilnehmende Beobachtung der Prozession zu ermöglichen. Es sei noch einmal Richard R. Bretell zitiert:

"In this painting, a Russian Realist, who flirted with the work of Manet and the Impressionists while working in Paris, returned to Russia and encapsulated the entire nation - its history, its political system, its religions and ideologies, its successes and failures - in a single canvas. Let us learn about the Russia - and the Realism - that gave rise to this painting" [Bretell, p. 59].

Das Russland kennenzulernen, das dieses Gemälde entstehen ließ, welches die gesamte Nation einschließt, und es zugleich als integralen Bestandteil der europäischen Geschichte zu sehen - dieses Anliegen eines Kunsthistorikers im fernen Texas deckt sich mit meinem Blick auf die russische und osteuropäische Geschichte. Und ich freue mich schon jetzt auf meinen nächsten Besuch in der Tret'jakov-Galerie.

\section{Гертруд Пикхан}

\section{МОЯ РОССИЯ: ТЕМЫ И ОБРАЗЫ}

Берлинский историк, профессор Гертруд Пикхан, наглядно показывает, что интерес к России у нее пробудился еще в юношеские годы, когда она стала посещать курс русского языка в Дортмунде. Помимо знакомства с русской классической литературой, это были культурные контакты, поездки в Россию, где она открыла для себя русскую живопись, особенно творчество Левитана и Репина, любовь к которым движет ее исследовательским интересом и по сей день. Круг ее научных интересов широк. Она исследует не только русскую живопись историю Пскова, но и феномен свободно мыслящих маргиналов и творческих личностей в условиях тоталитарного государства.

Ключевые слова: Россия и Германия; восточноевропейская история; история русской культуры; импрессионизм; реализм в искусстве; Берлин; Дортмунд; Москва; Псков; визуальная история; Рах Mongolica; Левитан; Репин.

Обычное дело для этнологов заниматься рефлексией относительно своих личностных предпосылок и подхода к теме своего исследования как обусловленного характером собственной социализации.

В исторических дисциплинах этот метод до сих пор почти не применялся, хотя именно исследования истории Восточной Европы предполагают множество вненаучных предпосылок. Так, до сих пор широко распространено мнение об отсталости Восточной Европы по сравнению с цивилизацией и демократией западного образца. С одной стороны, именно концепция multiple modernities ${ }^{1}$ позволяет рассматривать историю Восточной Европы без негативной проекции

1 Здесь и далее терминология автора статьи дается в оригинале.

(c) Пикхан Г., 2014

Quaestio Rossica • 2014 • №1 
чувства превосходства западного человека. С другой стороны, это не значит, что «темные стороны» истории и унижающие человеческое достоинство практики, характерные для русской истории, обязательно должны быть проигнорированы. Но не стоит сосредоточиваться именно на этих негативных сторонах, т. к. это может привести к появлению текстов, неадекватно отражающих людей и их исторически сложившиеся жизненные миры.

\section{Точка отсчета: Дортмунд (1973-1974)}

Где причина появления исследовательского интереса? Этот вопрос ставится еще слишком редко. А ведь именно он позволяет выявить не только личностные предпосылки, но и понять взгляды и представления, характерные для различных поколений. Оглядываюсь назад, в 1970-е гг., на город, находящийся на крайнем западе Федеративной республики, - Дортмунд. Большинству жителей Дортмунда как города промышленного была издавна свойственна социал-демократическая ориентация. Именно поэтому импульсы «новой восточной политики» во время правления федерального канцлера Вилли Брандта были с готовностью поддержаны. Особую активность и находчивость в этом проявляло Международное общество Рейн-Вестфалии ${ }^{2}$, старавшееся сделать для жителей Дортмунда мир, находящийся за железным занавесом, более открытым. Важной предпосылкой для близкого знакомства является знание языка. Поэтому общество организовало курсы русского языка для учеников гимназий города. Живо интересуясь иностранными языками и уверенно владея английским и французским, я решила пойти на такой курс. Мои родители, оба учителя средней школы и представители военного поколения (годы рождения 1917 и 1922), ничего не имели против, хотя и не были полностью свободны от антикоммунизма и предубеждений относительно «восточного блока», так распространенных среди бюргерских слоев населения Западной Германии. Посещение курсов русского языка не принесло ожидаемых результатов. Да это и не удивительно. Ведь наш учитель был чешским эмигрантом, вынужденным покинуть Прагу после событий 1968 г., и поэтому не испытывал особого желания открыть нам красоту русского языка и культуры. Это обстоятельство ни в коей мере не уменьшило мое восхищение русской литературой, в особенности произведениями Антона Чехова, которого я могла читать хотя бы в немецком переводе.

Дортмундское Международное общество также не стояло на месте и искало новые возможности, чтобы показать более дифференцированную картину супердержавы на Востоке Европы. С 1957 г. стали организовываться зарубежные дни культуры, посвященные определенной

${ }^{2}$ Auslandsgesellschaft Nordrhein-Westfalen e.v. 
стране. Начало положила Швеция и первой страной «восточного блока» стала в 1971 г. Венгерская Народная Республика. Наконец, в 1973 г. у нас в гостях был Советский Союз: «СССР. Зарубежные дни культуры города Дортмунда 14-25 мая 73» (см. ил. 1). В дополнение к заучиванию слов и зубрежке грамматики я получила все лучшее, что могла предложить официальная советская культура эпохи Брежнева. Программа содержала 37 страниц и простиралась от выступления балета Большого театра в Городском театре Дортмунда до курсов русской кухни в отеле «Римский император» ${ }^{3}$. На торжественном открытии, приуроченном также к открытию выставки «Космос - миру», в Золотом зале дортмундского манежа «Вестфалия» присутствовали мэр города Дортмунда Гюнтер Замтлебе, министр-президент земли Северный РейнВестфалия Хайнц Кюн (оба представители Социал-демократической партии Германии), а также посол СССР Валентин Фалин, внесший, еще до своего назначения в Бонн в 1971 г., вклад в разработку Московского договора между СССР и Федеративной Республикой Германия. Фалин завоевал симпатии жителей Дортмунда своим шармом и юмором в отличие от советских функционеров, известных из показов по телевидению. Запомнился курьезный ляпсус, когда он объявил себя «мужским зонтом» вместо «патрона» дней культуры ${ }^{4}$.

Вечером того же дня я стала свидетелем незабываемого события. В балете «Анна Каренина» на большой сцене Городского театра Дортмунда я впервые увидела Майю Плисецкую, испытав чувства восторга и необыкновенного счастья. Это было великое искусство на вершине своего времени, в лучших традициях русской культуры, знакомых мне из романов Толстого и рассказов Чехова. Чуткая способность девочкиподростка к восприятию сыграла здесь не последнюю роль. Спектакль оставил в моей душе глубокое впечатление. Этого нельзя сказать об учительницах нашей гимназии, слывшей консервативной. Безобидное представление Государственного кукольного театра города Москвы под руководством Сергея Образцова в актовом зале гимназии служило, по их мнению, исключительно коммунистической инфильтрации детей и юношества города. Схожее отрицательное отношение со стороны учительниц наблюдалось и в 1974 г., когда ученицы старших классов объявили о своем желании выбрать целью своего путешествия Прагу в рамках поездки группы школьников. Причиной отказа послужило утверждение, что в Праге за каждым углом дома прячется «красивый мужчина из Москвы», который только того и ждет, чтобы туда приехали гимназистки из Дортмунда. Это выражение стало в нашей гимназии крылатым. Вместе со своей матерью я совершила, наконец, в том же 1974 г., автобусную поездку в Прагу, где еще чувствовалась боль 1968 г. Я не помню, какие еще мероприятия я посещала. Программа была обширной и разнообразной: доклад советского министра культуры Екатерины Фурцевой (в программе «советский министр культу-

\footnotetext{
${ }^{3}$ Hotel Römischer Kaiser.

${ }^{4}$ «Herrenschirm» вместо «Schirmherr».
} 
ры» мужского рода!) $)^{5}$ «Развитие культуры в СССР и культурные связи с Федеративной Республикой Германия», выступления русского народного хора им. М. Е. Пятницкого, возложение советской делегацией венков к мемориалу, посвященному памяти жертв Второй мировой войны в Дортмунде, доклады о русской и советской литературе и об образовании взрослых в Советском Союзе, выступления лучших советских спортсменов-гимнастов, в том числе и Ольги Корбут, различные встречи советских граждан с жителями города. В заключение в манеже «Вестфалия» состоялся Бал народов, в котором участвовал оркестр западно-немецкого телевидения (Westdeutscher Rundfunk) вместе с Государственным оркестром Армянской ССР - немецкое телевидение вело прямую трансляцию по радио.

Помнится, Дни культуры Советского Союза нашли живой отклик у жителей Дортмунда, даже у моего отца, воевавшего юным солдатом в России в рядах немецкого вермахта. Об этом времени он вспоминал очень редко. Иногда в его речи мелькал «Russki». Несмотря на старания забыть прошлое, он порой замечал среди прочего, что в русском плену с ним обходились лучше, чем в британском. Сегодня я очень сожалею, что не расспросила своего отца, умершего в 1995 г., поподробнее о его военных воспоминаниях. Я могла только предполагать, насколько глубоко его занимали мысли о прошлом. И все же именно в то время я с большим интересом прочитала человечные и проникновенные рассказы Генриха Бёлля (того же года рождения, что и мой отец - 1917), в которых он поведал о своем военном опыте. Что в России Бёлля читали и чтили, мне было известно, и только подогревало мой интерес к нему и его произведениям. Интервью Клауса Беднарца с ним и Львом Копелевым в 1979 г. в Москве, называвшееся «Нет больше ненависти...», является лично для меня звездным часом немецкого телевидения.

На Пасху 1974 г. я поехала с группой молодежи в Москву и Ленинград. Только с совсем другими намерениями, чем мой отец или Генрих Бёлль во время войны, бывшие солдатами на Восточном фронте. Поездку финансировало Международное общество Рейн-Вестфалия. Это была первая продолжительная поездка, которую я предприняла без моих родителей. Восемь или десять дней нас сопровождали сотрудники туристического агентства международного молодежного туризма «Спутник». Оно организовало встречи с русскими молодежными группами в Москве и Ленинграде, диалог с которыми не смог состояться в том объеме, как я того хотела, из-за отсутствия общего языка, который мы бы понимали. Программа поездки, разработкой которой мы начали заниматься еще в Дортмунде, оказалась очень насыщенной. Больше всего мне запомнилась поездка на автобусе ранним вечером по одному из широких проспектов Москвы. Уже изряд-

5 В немецком языке, в отличие от русского, при обозначении профессии употребляются соответственно мужской и женский род, что является отчасти результатом гендерного поворота в гуманитарных науках, начиная с 1950-х гг. 
но утомившись от массы впечатлений, я вдруг обратила внимание на множество светящихся окон в серых многоквартирных домах. В это мгновение меня охватило сильное желание узнать, как живут люди за стенами этих домов, чем они занимаются, что их радует и какие заботы волнуют. Возможно, это прозвучит несколько сентиментально, но это был именно тот момент, когда я твердо решила заняться после окончания гимназии изучением славистики и восточноевропейской истории. Мое желание заглянуть за фасады домов и познакомиться с советскими людьми исполнилось в 1985 г., когда я, получив стипендию Немецкого научно-исследовательского общества ${ }^{6}$, в рамках написания своей диссертации из истории средневековой Псковской вечевой республики полгода жила и работала в Москве [Pickhan, 1992]. Это было время начала перестройки.

Хочется сказать, что своим интересом к России, ее истории и культуре я обязана Вилли Брандту, его новой восточной политике и Международному обществу Рейн-Вестфалия в Дортмунде. Можно назвать имена и других экспертов по Восточной Европе, получивших свои первые импульсы в Дортмунде. Это, например, мой коллега Клаус Зегберс, профессор политологии института Восточной Европы Свободного университета (год рождения - 1954). Здесь, в университете, на мой взгляд, в настоящее время формируется интересное исследовательское направление, ставящее своей задачей более подробно изучить поколенческие и социальные причины, мотивирующие немецких ученых заниматься исследованием Восточной Европы. И все же, рассматривая старые фотографии той поездки, мне, возможно, никогда не удастся ответить на вопрос, что же думали о нас тогда москвичи, в далеком 1974 г., увидевшие уверенную в себе молодежь из Западной Германии, раскованную, одетую в брюки-клеш (ил. 2).

Есть еще одно важное для меня воспоминание, уносящее меня в тот далекий 1974 г. в Москве. Это посещение Третьяковской галереи, где я впервые увидела картину Исаака Левитана «Над вечным покоем», приковывающую с тех пор мое внимание и являющуюся с недавнего времени моим исследовательским объектом (ил. 3). Каждый раз, приезжая в столицу, я совершаю паломничество в зал с картинами Левитана. Восприятие этих произведений конца XIX в. и их воздействие на меня производят всегда один и тот же эффект: в то время как за стенами музея пульсирует жизнь многомиллионного мегаполиса, в шуме машин, в спешке огромного количества людей в переходах и поездах метро, во мне созревает после многочасового созерцания картин некий образ, формируется некое чувство, которое я называю «моей Россией». В этих картинах я погружаюсь в нее, совершая путешествие во времени, проникаю в сокровенное пространство художника, его жизненный мир, пытаюсь прочитать его код и как можно дольше отодвигаю возвращение в такую порой жестокую действительность столичной повседневности. Тем не менее, это вненаучное,

${ }^{6}$ DFG - Deutsche Forschungsgemeinschaft. 
субъективное восприятие не является исключительно частным фактом моей созерцательности; оно, как и всякое восприятие, является культурно закодированным. Похожая мысль возникла у меня при посещении большой выставки картин из Третьяковской галереи в 2007 г., проходившей в манеже в Бонне. На ней, конечно же, присутствовали картины Левитана. Как видно из плакатного названия «Душа России», кураторы выставки обещали дать немецким посетителям возможность «заглянуть в русскую душу». Использование известного стереотипа в лейтмотиве выставки экспертами от искусства времени постмодерна могло быть понято как иронический вызов, нарушение стиля, хотя эта тема никак не обыгрывалась в каталоге.

\section{Visual History, или «История распадается на образы, не на историйки» (В. Беньямин)}

В 2007 г. я получила приглашение прочитать доклад на тему о новых перспективах исследования еврейской истории. История восточноевропейского еврейства является основной областью моих исследований с тех пор, как я посвятила свою докторскую диссертацию теме Всеобщего еврейского рабочего союза (БУНД) в Польше 19181939 гг. [Pickhan, 2001]. Возникновение моего интереса к этой теме также берет свое начало в 1970-х гг. и связано с Вилли Брандтом, с тем моментом, когда он встал на колени перед мемориалом Варшавского гетто в 1970 г. Это без сомнения было для меня самым впечатляющим политическим событием и повлияло на пробуждение моего интереса к судьбе уничтоженных нацистами жизненных миров восточноевропейских евреев. Этой темой я занимаюсь вот уже более 40 лет.

Когда я размышляла на тему моего доклада в 2007 г. в Потсдаме, мне вспомнился Исаак Левитан. При этом для меня было важным исследование моей израильской коллеги Эзры Мендельсон, посвященное еврейскому художнику польского происхождения Маурицию Готтлибу [Mendelsohn]. После его прочтения я занялась научными исследованиями об Исааке Левитане. Их первым результатом стало опубликование моего доклада, в котором я сравнила трех еврейских художников - Исаака Левитана, Мауриция Готтлиба и Макса Либерманна - в различных контекстах и из разных перспектив: Российская империя, Галиция и Пруссия/Германия [Pickhan, 2008, S. 247-264]. Следующим моим шагом было сосредоточение на одной единственной картине Левитана «Вечный покой»- со времени ее написания до позднего советского периода [Pickhan, 2011]. В 2012 г. появилась статья, в которой я исследовала некрологи, опубликованные в газетах летом 1900 г. после смерти Левитана [Pickhan, 2012, S. 591-616].

Совсем недавно я написала еще одну статью о прижизненной рецепции Левитана в немецкоязычном пространстве, в особенности 
Райнером Мария Рильке, которая должна выйти в 2014 г. в сборнике, посвященном российско-немецким культурным связям. Все эти публикации являются результатом подготовительных исследований, которые должны вылиться в отдельную книгу, в которой речь пойдет не о жизни и творчестве Левитана, но об их рецепции современниками и последующими поколениями. Особенно меня интересует вопрос, для кого, когда и почему еврейское происхождение Левитана имело значение или нет.

Эзра Мендельсон и Исаак Левитан обратили мое внимание на Visual History. Когда в 2007 г. я вновь посетила Третьяковскую галерею, мне подумалось при рассмотрении картин XIX в., что в них представлена вся история России, все важные темы того времени. Произведения художников могут быть историческим источником. Эту мысль я реализовала позже в лекции по русской истории XIX в. на примере произведений живописи, доставившей мне и моим слушателям большое удовольствие. Эта лекция послужит основой к написанию еще одной моей книги. В нее войдет и эпизод знаменитого «восстания четырнадцати» против академизма, связанный с неповиновением студентов Академии художеств, не желавших писать картины в рамках канона официальной живописи [Pickhan, 2011, S. 171-184].

\section{Основные аспекты моих исследований}

Первым из трех основных аспектов моих исследований являются процессы эмансипации и самоуполномочивания. Эту тему я начала разрабатывать, занимаясь Псковской вечевой республикой, которая подобно Великому Новгороду представляла модель, противоположную московскому централизму [Pickhan, 1992]. Свое продолжение этот исследовательский аспект нашел в разработке темы Всеобщего еврейского рабочего союза, сообщавшего его участникам - изолированному в обществе национальному и социальному меньшинству - новое самосознание и дававшего им раннюю концепцию современной мультикультурности. К процессам эмансипации относится и «восстание четырнадцати», ставших ядром позднего движения Товарищества передвижников, а также история джаза за «железным занавесом», служившего для молодого поколения в условиях господствующих культурных форм символом творческой свободы ${ }^{7}$. Последняя тема была разработана в рамках проекта, профинансированного фондом «Фольксваген». В то же время сложилось тесное сотрудничество с музыкальным журналистом Максимилианом Прайслером в рамках исследования биографии джазового музыканта Эдди Рознера, начинавшего свою карьеру в Берлине конца 1920-х гг., ставшего суперзвездой в Советском Союзе

7 Подробнее об исследовательском проекте: http://www.oei.fu-berlin.de/projekte/ jazz/index.html. 
во время войны, игравшего джаз, даже попав в ГУЛАГ, и закончившего свою жизнь в своем родном Берлине [Pickhan, Preisler].

Псков, джаз и евреи. При этом нельзя забывать еще одну область моих исследовательских интересов: о тще пенцы и «п ре красны е н е уд ач н и к и», которые мне более интересны, чем великие победители и герои в истории. Псковская городская республика была присоединена великими князьями к Московскому государству, управлявшемуся по строго централизованным принципам. БУНД исчез в бездне Холокоста. Джаз никогда не был в Восточном блоке музыкальным стилем, популярным среди широких кругов слушателей. И все же, ради того, чтобы играть «черную музыку» Америки, ее адепты готовы были подвергать себя репрессиям.

Восточноевропейские еврейские эмигранты в Берлине времен Веймарской республики - еще один большой исследовательский проект прошлых лет - также оставались изгоями, изолированными в обществе. Несмотря на это, они смогли создать богатую нюансами и в высшей степени творческую среду - свой микрокосмос ${ }^{8}$ Из него вышел Эдди Рознер, образовавший своеобразное связующее звено обоих проектов - о джазе и еврейской эмиграции Берлина.

В конечном итоге, считаю своей прямой обязанностью проведение критического анализа парадигмы отсталости в русской и восточноевропейской истории. Она берет свое начало уже в Средние века. И сегодня можно часто услышать мнение, что «татарское иго» отбросило Россию назад и послужило причиной ее затянувшейся отсталости, чувствующейся, якобы, по сей день. Напротив, новые исследования ясно показывают, что средневековая Русь ни в коем случае не была изолирована после 1240 г. и тем более не была отброшена к азиатскому деспотизму. Русь была включена в «Pax Mongolica» и в обширную торговую и коммуникационную сеть [Pickhan, 2009, S. 113-137]. Тем самым исчезает всякое основание для предположений об истоках некой отсталости России, берущей свое начало в Средневековье. Если же взглянуть на XIX в., а именно на 1863 г., то мы увидим, что 14 петербургских студентов порвали с академизмом гораздо раньше, чем это сделали художники Германии и Австрии в ходе движения эмансипации 1890-х гг. («Sezession»), т. е. три десятилетия спустя.

\section{"Let us learn about the Russia... that gave rise to this painting»"}

Пожалуй, самый знаменитый русский художник XIX в., Илья Репин, сформировался как профессионал в среде молодых бунтарей в искусстве. С Иваном Крамским, одним из лидеров Движения четырнадцати, Репина связывала тесная дружба. «В поисках России» html

${ }^{8}$ URL: http://www.oei.fu-berlin.de/projekte/charlottengrad-scheunenviertel/index.

9 «Давайте изучать Россию... тогда мы сможем подняться до понимания ее живописи». 
так называлась выставка работ И. Е. Репина, показанная в 2003 г. в Берлинской национальной галерее. Там же была выставлена картина «Крестный ход в Курской губернии», впервые показанная на 11-й передвижной выставке в 1883 г. В ней художнику удалось создать монументальный и в тоже время дифференцированный калейдоскоп российского общества того времени. Картина, находящаяся сегодня в Третьяковской галерее, завораживает зрителя, втягивая его в свое гравитационное поле. Под его влиянием находится и американский исследователь истории искусства, эксперт по французской живописи XIX в. в далеком Tехасе. Ричард Р. Бретел (Richard R. Bretell) призывает рассматривать искусство передвижников прежде всего как искусство и уже потом как «русское». Он обращает наше внимание на то, что русские художники, как за счет обращения к национальным истокам, так и ввиду их восстания против авторитетов, должны рассматриваться в контексте общеевропейского движения авангарда: «Realism, for the Russians, was part of a general European movement rather than an isolated response to Russian social and aesthetic conditions... Unlike the Impressionists and the various groups in France, they were well organized, made money, and succeeded in their aims of promoting Russian art throughout the country» [Bretell, p. 53] ${ }^{10}$.

Художественное движение, берущее свое начало в 1863 г. как «восстание четырнадцати», показывает, что Россию в культурном и интеллектуальном плане ни в коем случае нельзя назвать отсталой, напротив - она была на высоте своего времени. Художники в своих картинах восхищаются русской жизнью и в то же время критикуют ее, как метко сформулировал Бретелл. Картина Репина «Крестный ход» наглядно показывает это. В движущейся процессии видны традиционно одетые крестьяне, простые женщины в платках, школьники со своим строгим учителем, упитанный священник с красным лицом (возможно, от злоупотребления спиртным), сытая помещица, несущая икону, стражи порядка, избивающие нарушивших строй. Единственное одухотворенное лицо у горбатого нищего с костылем. За исключением двух бедно одетых испуганных паломниц, идущих за ним, он, возможно, единственный, движущим мотивом которого является религиозность. Очевидно, что именно ему художник отдает свои симпатии. Репин мастерски вовлекает зрителя в движение картины, позволяя ему, заворожено принять участие в процессии. Процитируем еще раз Ричарда Бретелла: «In this painting, a Russian Realist, who flirted with the work of Manet and the Impressionists while working in Paris, returned to Russia and encapsulated the entire nation - its history, its political system, its religions

\footnotetext{
10 «Русский реализм был частью общеевропейского движения, а не изолированным ответом на российскую действительность и в рамках национальной эстетики... В отличие от импрессионистов и различных групп во Франции, они были прекрасно организованы и финансово успешны, преуспели в достижении своих целей по поддержанию русского искусства по всей стране».
} 
and ideologies, its successes and failures - in a single canvas. Let us learn about the Russia - and the Realism - that gave rise to this painting» [Bretell, p. 59] ${ }^{11}$.

Узнать Россию, создавшую в своих недрах этот шедевр, представляющий из себя квинтэссенцию всей нации, видя в этой картине в то же время неотъемлемую часть европейской культуры - именно такой взгляд на русскую и восточноевропейскую историю объединяет меня с историком искусства из Техаса. В остальном же - меня радует мысль о возможности вновь посетить Третьяковскую галерею.

Bretell R. R. The Wanderers and the European Avant-Garde // The Wanderers. Masters of $19^{\text {th }}$ Century Russian Painting / ed. E. K. Valkenier. Dallas : Dallas Museum of Art, 1991. P. 49-59.

Mendelsohn E. Painting a People. Mauyrycy Gottlieb and Jewish Art. Hanover; London : Brandeis Univ. Press, 2002. 279 p.

Pickhan G. Gospodin Pskov. Entstehung und Entwicklung eines städtischen Herrschaftszentrums in Altrußland. Berlin, 1992. (Forschungen zur osteuropäischen Geschichte. Bd. 47).

Pickhan G. „Gegen den Strom“. Der Allgemeine Jüdische Arbeiterbund („Bund“) in Polen 1918-1939. Stuttgart ; München : Deutsche Verlags-Anstalt, 2001. (Schriften des Simon-Dubnow-Instituts Leipzig. Bd. 1).

Pickhan G. Levitan-Liebermann-Gottlieb. Drei jüdische Maler in ihrem historischen Kontext // Osteuropa 5. 2008. 8-10. S. 247-264.

Pickhan G. Von der Kiever Rus' zum Moskauer Reich. Transkulturelle Verflechtungen in Osteuropa 1240-1533 // Die Welt 1250-1500 / hg. T. Ertl, M. Limberger. Wien, 2009. (Reihe Globalgeschichte. Die Welt 1000-2000). S. 113-137.

Pickhan G. „Aufstand der Vierzehn“. 1863 als Schlüsseljahr für die bildende Kunst in Russland // Schlüsseljahre. Zentrale Konstellationen der mittel- und osteuropäischen Geschichte. Festschrift für Helmut Altrichter zum 65. Geburtstag / hg. von M. Stadelmann, L. Antipow. Stuttgart : Franz Steiner Verlag, 2011a. S. 171-184.

Pickhan G. „Uber der ewigen Ruhe“. Zur Entstehungs- und Rezeptionsgeschichte einer russischen Stimmungslandschaft [Электронный ресурс] // Zeitenblicke 10. 2011 b. Nr. 2. URL: http://www.zeitenblicke.de/2011/2/Pickhan/index_html (дата обращения: 30.04.2011).

Pickhan G. „Lewithanisierende Rußlandsucher“. Isaak Levitan und die zeitgenössische Rezeption seines Werkes // Jahrbücher für Geschichte Osteuropas. Bd. 60. 2012. S. 591-616.

Pickhan G., Preisler M. Von Hitler vertrieben, von Stalin verfolgt. Der Jazzmusiker Eddie Rosner. Berlin ; Brandenburg : Be.bra, 2010.

Translated by Andreas Keller The article was submitted on 28.01.2014

Гертруд Пикхан, проф. Германия

Свободный университет Берлина pickhan@zedat.fu-berlin.de
Gertrud Pickhan, prof. Germany

Free University of Berlin pickhan@zedat.fu-berlin.de

11 «В этой картине русский реалист, увлекавшийся работами Мане и импрессионистов, работая в Париже, запечатлел весь народ - со своей историей, политической системой, религией и идеями, успехами и неудачами. Давайте узнаем Россию и реализм, породивший эту картину».

(C) Keller A., 2014

Quaestio Rossica • 2014 • №1 